\title{
Connecting Teacher Leadership Qualities with ICT Changes
}

\author{
Elizabeth F. Majocha
}

\begin{abstract}
Teacher leaders are challenged to encourage colleagues to use information communication technology (ICT) in their classrooms. This multi-case study explored the qualities of teacher leadership in a $K$ to 12 public school system with a high enrolment of Aboriginal students. Data were collected from semistructured interviews with four teachers, the researcher's observations and field notes, and a paper-based survey that the teachers in the four schools where the participants worked completed. The constant comparative method was used to code and categorize the data into themes. The findings show that (a) to maintain their leadership, teacher leaders need to learn, explore, and share; (b) to earn respect, teacher leaders must be knowledgeable, humble, supportive, and excited; (c) to earn leadership, teacher leaders must encourage, respect, and network; and $(d)$ to preserve their leadership, teacher leaders must be approachable and accept feedback from colleagues and students.
\end{abstract}

\section{Introduction}

Teachers face challenges in using information communication technology (ICT) in their classrooms, because "ICT changes fundamentally the teacher's role, which goes beyond the traditional way of working" (p. 4) [1]. Kalogiannakis stressed that teachers need to change to try new methods and technologies for their classroom teaching. [2]Even though school leaders, who are confronted with complexities and astonishing demands on the job, play an important role in supporting as well as encouraging their teaching staff, teacher leaders fulfil their impossible job description [3]. When teacher leaders and their colleagues influence the entire school-such as setting up computer labs-they offer valuable assistance to school leaders. School leaders succeed only when teacher leaders are driven with the resolute purpose of improving student learning [4]. In addition, teachers who lead others within the school as well as the community introduce new ways of integrating technology into their schools.

Unfortunately, some teachers who attend summer workshops to learn to integrate technology into their classrooms find that they cannot integrate it into their pedagogy [5]. Glazer, Hannafin, and Song asserted that when learning is not within the teacher's authentic environment, the acquired knowledge and skills become more abstract and less meaningful. Yet, although they face the challenge of integrating technology into their pedagogy, some teachers devote extra effort to it and see positive results with their students. When they promote student learning outcomes, they are more likely to sustain and enhance their efforts to integrate technology into their classroom teachings. These teachers often share their experiences with technology integration through informal interactions in the hallway or the staffroom [6]. As colleagues use technology to improve learning, they will need ongoing technical support and mentoring from trusted peers [5], teachers who hold similar views on the use of ICT to enhance student learning. Therefore, technology integration, specifically, integrating the Internet into classroom teachings, is the reason that teachers have taken on leadership roles [7]. Supovitz, Sirinides, and May asserted that teachers who step forward to support and lead their peers during technological change work collegially with their associates to examine their instruction and determine the effect of technology on student learning. Teacher leaders work with colleagues to shape school improvements and guide other teachers toward a collective goal [6].

\section{Research Rationale}

The purpose of this exploratory multi-case study was to explore with four teacher leaders their perceptions of the leadership qualities that sustained them through periods of technological change. During my 28 years of teaching experience in combining technology and curriculum development, I have become the resource person for technological undertakings at our institute. In this role, and through 
my interactions with many colleagues over the years, I have heard many perspectives on the profound impact of technology on teaching and learning. I have seen how technology changes teachers' delivery content, their interactions with students, and their management of information. As well, I have seen the visible gaps in teacher leaders' knowledge, skills, attitudes, values, and practices in the area of educational technology. For example, teachers feel ineffective or incompetent when they are unsure of how to integrate computer skills into the curriculum. Sometimes low self-esteem with regard to the use of computer technology exposes teachers' frustrations. Teacher leaders frequently struggle to make education more engaging and reflective for their own students as well as for their colleagues' students. Often they find that the use of digital technologies such as the Internet, interactive whiteboards, iPhones ${ }^{\mathrm{TM}}$, iPods ${ }^{\mathrm{TM}}$, iPads ${ }^{\mathrm{TM}}$, and so forth can assist them and their colleagues in creating more engaging and reflective learning opportunities.

I anticipated that a better understanding of the practices that sustain teacher leaders would help both school leaders and teacher leaders to make more informed decisions to support the integration of ICT into classrooms. To shed light on the problem, I addressed the following research questions:

1. How do teacher leaders maintain their leadership roles during technological change?

2. How do teacher leaders earn the respect of the people whom they lead?

3. How do teacher leaders earn their leadership roles?

4. How do teacher leaders preserve the leadership and respect of colleagues during technological change?

In this research, conducted in a rural $\mathrm{K}$ to 12 school district in the province of Saskatchewan during the 2008-2009 school year, I explored the practices of teacher leaders during a time when ICT technologies were being introduced into their schools. I sought the perspectives of self-selected leaders and those whom they led during the technological reform. More specifically, I examined the practices that the teacher leaders used to support their colleagues and students within a learning community.

\section{Definitions of Key Terminology Used in This Study}

Teacher leaders: Informally, those "who naturally emerge among their colleagues as trusted and respected catalysts" (p. 80) [8].

Teacher leadership: The capability of teachers to promote change, "lead within and beyond the classroom, identify with and contribute to a community of teacher learners and leaders, and influence others towards improved educational practice; and accept responsibility for achieving the outcomes of their leadership" (p. 6) [9].

School leaders: School principals who use "a combination of influence and support strategies to achieve school goals" (p. 546) [10].

Colleagues: Teachers "who work together [with teacher leaders] in pursuit of common goals and continuous improvement" (p. vii) [11].

$I C T$ : Information communication technology, which refers "to all technologies used for processing information and communication ... [such as] communication technology, multimedia, and networking, especially the Internet" (p. xxix) [12].

Technology: The hardware and software of all digital "technologies used for processing information and communicating" (p. xxix) [13].

Technological change: Change in which the dominant technology is replaced with something new, which helps teachers to accommodate new knowledge and pedagogical/technological skills [14].

\section{Literature Review}

Leadership is not a problem that is solved; rather, it entails an evolving and crucial need that shifts and changes as communities change. Sergiovanni [15] asserted that "there can be no leadership if there is nothing important to follow" (p. 167). Therefore, individuals will recognize a leader with commitment and values and turn to such a leader to seek direct answers to their questions about teaching practices. Attributes such as compassion, consideration, and appreciation help teacher leaders to maintain the attitude that teachers must collaborate and help one another to make the school a better place [5].

Teacher leaders quietly do their job and, at the same time, quietly influence their colleagues [6]. Reeves pointed out that teacher leaders are positive instigators of change and influence the performance of their colleagues and school leaders. However, for change to take place, Mulford [16] contended that school leaders must be challenged "to create synergistic effects: the accumulation of a number of effects developed with others within the school and community over time in the same direction" (p. 2). They are not imprisoned by academic setbacks or school history or mistakes of administrative decision makers or even defeats along the way because they are free to make choices [5]. Therefore, because teacher leaders who integrate ICT into classroom teaching encourage their colleagues to use the technology, there is a need to find a category within a theoretical framework or model that will best suit the complexity of teacher leadership during technological change. 
Distributed leadership theory clarifies the teacherleadership domain, which, as Spillane, Halverson, and Diamond [17] explained, "incorporates the activities of the multiple individuals in a school who work at mobilizing and guiding a school's staff' (p. 16). Spillane et al. argued that distributed leadership theory involves multiple leaders, along with followers, who use tools to perform particular leadership tasks. Therefore, leadership practice is viewed as the result of interactions among school leaders, followers, and their situations [17]. Specifically, Spillane et al. accentuated that interactions between leaders and their colleagues are based on a particular context within specific tasks. In the performance of a task, collaborative forms of engagement emerge and interpersonal synergies develop that strengthen the close working relationship among colleagues. This mutual interpersonal bond creates "a sense of belonging that makes them more amenable to taking direction from others" (p. 32) [7].

With technological change being constant, the work of leadership requires collaboration, diverse expertise, and different forms of leadership flexibility [12]. Collaboration is required when a group of teachers work towards a common goal. They must group themselves with others and pool their expertise, skills, and knowledge to complete a task [10]. Leadership is evident when others recognize ideas of the teacher leaders that are important to them [10].

When members of schools work together, they gain an intuitive understanding as they develop close working relationships [10]. For close collegial rapport, the degree of influence of one colleague over the others depends on how much the others trust that person [18. 8]. Therefore, the leader and his/her followers must become interdependent, and everyone plays different roles and shares responsibilities [7].

Distributed leadership is desirable only when the quality of leadership contributes to the effectiveness of students' learning. Even though distributed leadership emphasizes collaboration and distributed responsibilities, Harris [7] cautioned that problems with distributed leadership arise when school leaders see it as a way to download duties rather than to improve teacher learning. Therefore, for teachers to lead in schools, they must be role models as learners. In Leithwood's [19] transformational leadership model, Merideth's [20] REACH model, and Collins' [21] good-to-great level-5 leadership model, the paradigms indicate that teacher leaders need to work with their colleagues to attain the vision of improved learning in schools. These authors explained that we do not learn isolated facts and theories in some abstract manner that separates theory from lifelong experiences; rather, we learn in relationship to our other knowledge, our beliefs, our prejudices, and our fears.

Teacher leaders must continually learn what change has to offer to be able to lead others successfully. Teachers are faced with the task of integrating content, pedagogy, and technology into their classroom teachings. Koehler and Mishra [22] asserted that, because teachers have their own constraints that make them more suitable to certain tasks, they are confronted with the challenges that new technologies present. Teachers with ICT experience find that acquiring new knowledge and skill sets can be challenging, especially when it is a time-intensive activity that must fit into a busy schedule.

Because teachers face the task of integrating content, pedagogy, and technology, Koehler and Mishra [22] developed a TPCK framework to show that teachers relate creative ideas to the use of the technologies already available to them. The TPCK concept is embedded within three types of knowledge: content, pedagogical, and technological. Content knowledge is the actual subject matter that is being taught, pedagogical knowledge is the technique of presenting the material in the classroom along with the assessment of students' learning, and technological knowledge is the ability of a teacher to accomplish a variety of tasks using the information to implement that technology as well as to create different ways to accomplish a task.

The number of computers in schools is steadily increasing, and the complexities of using ICT in teaching and learning are becoming greater; as a result, TPCK takes into account "the phenomenon of teachers learning how to teach with technology" (p. 8) [23]. Computer technology is a tool that teachers use to encourage students to explore in their learning process, but teachers face two challenges: (a) Those with knowledge of the subject's content must select methods or techniques that are meaningful to the students; (b) they must construct knowledge, acquire skills, and then examine how the learning changes because of the technology they are using [22].

TPCK prompts teacher leaders to ask, "How can I combine technology and pedagogy to become an effective teacher?" The framework of learning and pedagogy, as Koehler and Mishra [22] explained it, is that teacher leaders must develop TPCK to effectively integrate educational ICT into curriculum-based instruction. Teacher leaders who lead their colleagues through integrating ICT into their classroom teachings demonstrate the interdependence of technology, pedagogy, and content so that the knowledge of each aspect is flexible enough to fit any program that they teach and so that they blend together to make learning relevant to their students. 
Because leadership is a relationship between those who lead and those who choose to follow, teacher leaders acquire leadership skills to sustain learning within a school community through their working relationships. A good experience from the richness of a learning environment makes a lasting impression on both teacher leaders and their followers [23]. An effective means of conveying teacher leadership qualities is through the use of case studies.

\section{Research Methodology}

With regard to the specifics of the research design, after the ethics documents were approved, I contacted the director of education of the public school division for approval to deliver pamphlets to four selected school sites. Before the interviews with the teacher-leader participants began, I conducted a pilot case study. I visited each of the first four teacher leaders who volunteered to participate in the study to explain the purpose of the research and to leave each a consent form. During the visits, which occurred at agreed-upon times, I informed each class why I was observing their teacher and passed out a consent form for the parents of the students to sign. My interviews with and observations of the four volunteers began in January and concluded in April 2009. From the data collected, I developed a survey-form base from the information that I gleaned from the interviews. I then asked the principals of each of the four teacher leaders for an allotted time during a staff meeting to explain to the teachers' colleagues the background of and reasons for my paper-based survey. After a five-minute presentation, I left a consent letter and survey forms with each staff member. I completed my visits to the case-study sites in May 2009.

In the data analysis I used a modified version of Glaser and Strauss's (as cited in [24]) constant comparative analysis, which involved explicit coding and analytic procedures that helped me to make sense of the findings. Because all qualitative data analysis methods involve coding data into themes [24], in this exploratory case study I used the constant comparative method, which consists of four stages that involve the analysis of qualitative information that emerges as themes or codes. In addition, I used triangulation to validate the consistency of the data and to remain aware of differences that might appear during the analysis [24].

Because no instrument is free of errors, this study had several limitations: (a) The study involved an examination of a specific population and setting; (b) I have a keen interest in the subject, the qualities of teacher leadership; (c) this study did not include teacher leadership issues associated with the gender, ethnicity, age, religion, or socioeconomic status of the participants; and (d) my presence as the interviewerresearcher might have influenced the responses in the semistructured interviews.

\section{Findings}

The purpose of this exploratory multi-case study was to explore with a sample of four teachers who were using technology in a $\mathrm{K}$ to 12 school system their perceptions of how they led their colleagues during technological change. Table 1 briefly summarizes the participants' experiences.

\section{Table 1. Summary of Participants' Experiences}

\begin{tabular}{|c|c|c|c|}
\hline Participants & $\begin{array}{c}\text { Teaching } \\
\text { experience }\end{array}$ & $\begin{array}{c}\text { Technology } \\
\text { used }\end{array}$ & $\begin{array}{l}\text { Additional } \\
\text { skills }\end{array}$ \\
\hline Phyllis & 5 years & $\begin{array}{l}\text { *Interactive } \\
\text { Whiteboard } \\
\text { *Internet }\end{array}$ & $\begin{array}{l}* \text { Seminars } \\
\text { for } \\
\text { colleagues }\end{array}$ \\
\hline John & 8 years & $\begin{array}{l}\text { *Interactive } \\
\text { Whiteboard } \\
\text { *Internet } \\
\text { with } \\
\text { Google }\end{array}$ & $\begin{array}{l}\text { *Facilitator } \\
\text { *Seminars } \\
\text { for } \\
\text { colleagues }\end{array}$ \\
\hline Michael & 25 years & $\begin{array}{l}\text { *Interactive } \\
\text { Whiteboard } \\
\text { *Internet }\end{array}$ & $\begin{array}{l}\text { *Computer- } \\
\text { assisted } \\
\text { technology } \\
\text { (CAT team) }\end{array}$ \\
\hline Margaret & 10 years & $\begin{array}{l}\text { *Interactive } \\
\text { Whiteboard } \\
\text { *Internet } \\
\text { *Document } \\
\text { camera } \\
\text { *Senteos }\end{array}$ & $\begin{array}{l}\text { *Seminars } \\
\text { for } \\
\text { colleagues } \\
\text { *Microsoft } \\
\text { technology } \\
\text { innovator }\end{array}$ \\
\hline
\end{tabular}

In searching for information on the qualities of teacher leadership, I contextualized the key findings from three in-depth interviews of four teacher leaders, field observations of the four teacher leaders, and selfadministered questionnaires that the teachers in each of the four teacher leaders' schools completed. The four major findings that emerged are as follows:

1. To maintain their leadership of their colleagues, teacher leaders need to continuously learn to use and explore or 'play' with technology and then share new ideas with their colleagues.

2. Because quality education for students is the foremost concern of all teachers, to earn the respect of the people whom they lead, teacher leaders must be both knowledgeable and experienced in the use of technology, supportive of their colleagues who use technology in their classes, and humble as well as excited about using technology for the benefit of learners. 
3. All teachers must be encouraged to "get on board" with technology, which presents an opportunity for teachers to learn and network and for teacher leaders to retain trust and earn the leadership of the people whom they lead.

4. To preserve their leadership role and the respect of their colleagues during technological change, teacher leaders must be open and approachable to students and colleagues, which results in such success indicators as both students' and colleagues' increased use of information technologies and important feedback from learners.

\section{Discussion of Findings}

Using ICT in their classroom teaching is a challenge for teachers. Those who are intrigued and excited by the possibilities of improving student learning through the use of digital technology are leading their colleagues through trying a wider use of technology in their instructional practices. The qualities of teacher leaders who lead colleagues during ICT changes are the factors that promote successful integration into their pedagogy.

Four themes related to the qualities of teacher leadership emerged from the findings (Figure 1), which I organized into a quadrant of teacher leadership:

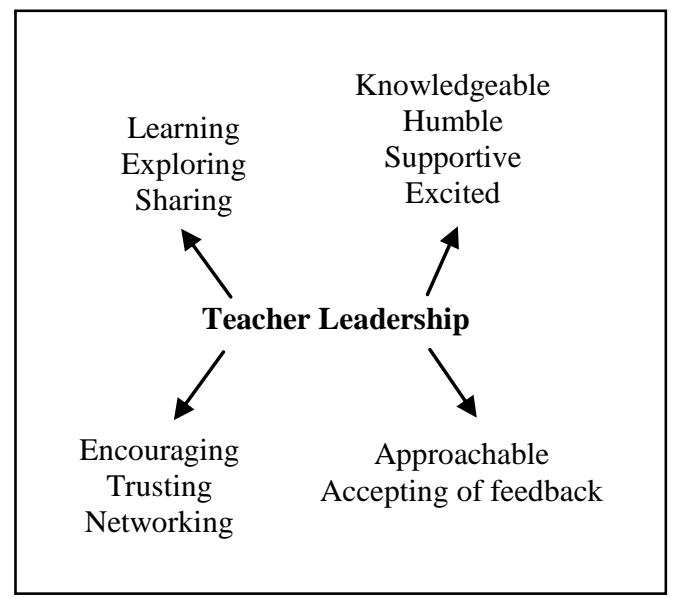

\section{Figure 1. Teacher leadership themes from this study}

The first major finding of this research is the importance of regularly exploring, learning, and sharing new technology. Change takes place as a result of the exploration of what technology can do to improve teachers' learning and classroom teaching, as well as students' learning. For technological information to be meaningful to teachers, they need to learn at a comfortable pace. Two participants suggested that for adults to learn new materials properly, the learning process must relate to the learners' experiences. Therefore, teachers must understand ICT broadly enough to apply its use from their everyday lives to their pedagogy as they must continually adapt to changes to information technology [22]. In addition, what they learn must relate to their experiences with technology in the classroom. They construct new knowledge through collaboration and participation in cooperative activities that are personally meaningful to learners [22]. Teacher leaders need to share what they learn with those who have an in-depth interest in technology, because colleagues will approach a leader with technological expertise. Adult learners construct knowledge that they gain from experts, and teacher leaders encourage learners to share concerns, which creates an environment for collective listening [4,2].

For teacher leaders to remain at the forefront of ICT, they must continuously learn which changes in technology will be effective for student learning. Teacher leaders who continuously grow intellectually acquire expertise and are able to successfully learn the learning of their colleagues. Yet, to acquire this expertise, all participants indicated that they need to try, fail, change, and adapt strategies and overcome obstacles after many trials. One of the participants warned that should teacher leaders stop learning because they feel they are good at what they do, everyone will pass the teacher leader by.

Learning is a challenge that requires effort, selfdiscipline, and professional will [1]. When teacher leaders venture into uncharted territory in the field of computer technology, they must be self-disciplined to be able to explore and successfully learn new applications or to use new technological devices to discover how teachers and students can benefit from their use. All four teacher-leader participants whom I observed demonstrated the benefits of continuous learning. Moreover, they were curious about which technology they could use to improve learning in their schools.

To achieve positive results from exploring and learning while they use ICT, teacher leaders must clearly recognize the need for short- and long-term results for their colleagues to learn effectively. Collins [21] maintained that for leaders to retain clarity and understand the benefits of learning and using technology, they must use the hedgehog test (Figure 2 ), which is composed of three circles. The first circle asks, "What are you deeply passionate about?" (p. 19) — what it is about technology that ignites that passion? This means that teacher leaders' value for technology must correlate with their school's mission. The second circle asks, "What can you be the best in the world at?" (p. 19)—what can leaders contribute to 
the learning environment for their colleagues and students? This question makes teacher leaders aware of what they cannot be best at. To answer this question, Collins maintained that teacher leaders need to go beyond their competencies. The third circle asks, "What drives your resource engine?" (p. 19)specifically, can time or emotional commitment to the vision of using technology to excite learners drive teachers leaders?

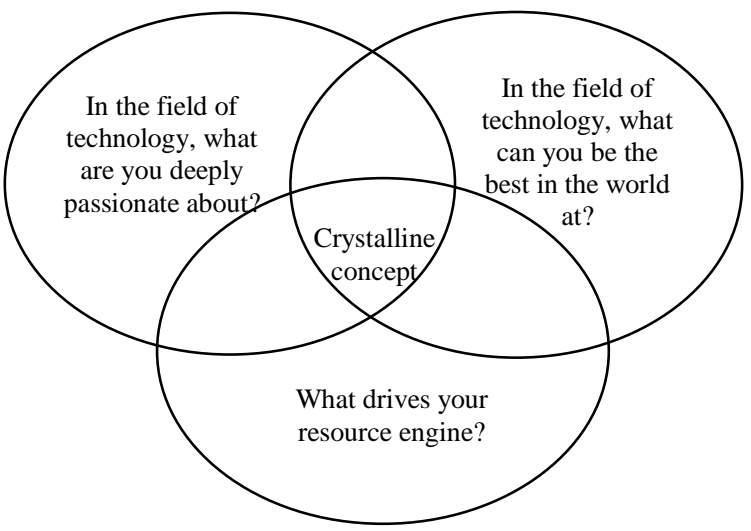

Figure 2. Collins' [21] hedgehog concept

When teacher leaders answer the three questions, they will come to a crossroad. At the intersection of the three circles, a concept emerges. Specifically, when teacher leaders arrive at the intersection, they must find the one core concept that makes learning to use technology less complex.

Even though teacher leaders know what they can be the best at, learning and teaching, according to one participant, is a continual cycle: Technology is always changing, and there is always something improving. Teacher leaders are challenged to stay abreast of the changes in technology because even their youngest students use technology actively outside of school. Therefore, teacher leaders can begin to understand and adapt to information technology by allowing their students to demonstrate how different applications work.

To evaluate the use of technology in learning, teacher leaders need to ask whether it aligns with the school's mission. Furthermore, to maintain their leadership, teacher leaders need to learn, explore, and share.

The next major finding of this research is that teacher leaders must earn respect, and they must be knowledgeable, humble, supportive, and excited. Because quality education is the foremost goal, the teacher-leader participants explained that when changes in technology are connected to students' needs, they can help their colleagues to adapt to the changes. Teacher leaders adapt their teaching methods from the traditional lecture style to student-centred learning, and they must be knowledgeable about the use of technology in schools to assist teachers with making this shift. However, teacher leaders need to be flexible and adaptable when they try to make sense of the challenges that both leaders and colleagues face. For teacher leaders to experience and to acquire knowledge on the use of technology, they must first acquaint themselves with new application programs. Teacher leaders gain experience with technology by working with technology and by doing. As one participant suggested, one needs to try it, and if it is not going well, then keep adapting until one finds what works best to bring the subject across to the learners. They are passionate and excited when they observe technology benefitting their students. Likewise, they decline to use computers or applications that have little or any relevance to improving the learning environment.

When interested and passionate people work together, support is readily accessible. But when teacher leaders meet resistance, they need to patiently explore the core of the resistance. Therefore, to maintain the respect that teacher leaders need, they must be able to focus on their colleagues' accomplishments. With humility, they can admit that they do not know everything and are aware of what others can offer to improve student learning. Teacher leaders must find pockets of energy in colleagues who have a shared vision to improve the school's learning environment. The critical factor in colleagues' sharing of a technological vision is the teacher leader's support. Collins [21] asserted that when interested and passionate people work together to reach a vision, support is readily accessible. They encourage their colleagues to share their expertise and responsibilities to create a positive learning environment for students and staff.

To maintain the support and respect of their colleagues, teacher leaders need to focus on others' accomplishments. During my observations, I found that colleagues approached the teacher leaders for guidance in implementing technology in their schools. When they are humble, their colleagues feel their respect. Humility, as Collins [21] defined it, is the ability to "grasp the fact that you do not yet understand enough to have the answers and then to ask questions that will lead to the best possible insights" (p. 75). I found that the four participants' virtue of humility was evident when they recognized how much they needed to know and could learn from their colleagues. Teacher leaders cannot know all of the answers in the process of using technology; therefore, they must work alongside their colleagues who have expertise in certain areas. The teacher leaders whom I observed were confident in the use of technology in their classroom teaching and demonstrated humility in 
their continual work with their colleagues on the use of technology to sustain quality education for their students. In addition, they recognized others' accomplishments and the changes that were implemented in the school.

The teacher leaders who participated in this study were concerned about the quality of education offered to all students in general. They were ambitious for the cause or the mission of their school and not for themselves. They had the will to do whatever it took to make good on that ambition. These teacher leaders were aware that their co-workers were "highly mobile knowledge workers" (p. 13) [21], and they encouraged their colleagues to share their expertise and responsibilities to create a positive learning environment for students and staff.

The subsequent significant finding of this study is that, to earn leadership, teacher leaders must encourage, trust, and network with colleagues. They must encourage their colleagues to use technology in their classroom teaching, which requires that they be patient as well as listen and attend to their colleagues' needs. When their colleagues resist the use of technology, teacher leaders need to understand the source of that resistance. One of the teacher leader participants observed that even though not all teachers are comfortable with using technology, they will soon use it because of the demonstrated need. However, even though teachers are aware of the need to use technology, they lack the technical training and pedagogical expertise to carry through the lesson in an efficient manner. Yet teachers use different types of technology such as iPods ${ }^{\mathrm{TM}}$, iPads ${ }^{\mathrm{TM}}$, and iPhones ${ }^{\mathrm{TM}}$ in their daily lives; they do not resist technology itself. Still, teachers are challenged to integrate ICT into their pedagogy. They may face the challenge of the availability of time to integrate ICT into learning, but, as one participant stressed, "You must take the time to play and experiment."

However, to encourage their colleagues to use technology, teacher leaders must be patient. The participants demonstrated patience by listening, caring, and tending to their colleagues' needs. To further understand which technological tools will improve their teaching pedagogy, teacher leaders need to work alongside their colleagues to enhance their own technological expertise. When teachers see someone actually use technology in the classroom, the idea appears to become more concrete for them. One of the participants observed that once colleagues can use technology in a particular way, "it will spread out from there and enable them to share their values to enhance student learning."

It is impossible to foster relationships or teamwork in a school without trust [8]. Within a trusting environment, both teacher leaders and their colleagues are respected and honoured. With trust, teacher leaders can encourage active involvement and the free exchange of information. They are able to create professional learning communities that include ongoing, on-task, onsite dialogue to improve student achievement.

Teacher leaders who are accessible to their colleagues are crucial to maintaining trust. Donaldson [8] emphasized that it is impossible to have a relationship - or teamwork or collaboration-in a school without trust. During my field observation, I found that, to sustain trust, teacher leaders need to be accessible to learners who are attempting to improve their use of technology in their classes. As a result, "in trusting environments, teachers are able to encourage one another's thinking about instruction and the ways in which new reforms could affect student learning" (p. 407) [25]. Furthermore, relationships will not develop unless everyone's perspectives are honoured-which is the essence of respect [25]. Trust is created through mutual respect and a shared commitment with their peers to student learning. Specifically, professional trust is manifested in shared decision making that involves the standards and values that colleagues mutually endorse.

Peer networking, which involves dialogues between practitioners with common purposes [26], reduces teacher isolation and encourages shared meaning among teachers [4]. During my observations, the four teacher leader participants, when they networked with their colleagues, encouraged them to offer their technological knowledge to others who are seeking technological/pedagogical integration resources. Teachers network when they are committed to improving student learning [20]. However, when the dialogue between teacher leaders and their colleagues has little connection to student learning, teachers remain isolated in the classroom. To eliminate teacher isolation, teacher leaders need to be available to others to assist them in focusing on the benefits of technology to student learning.

Finally, this study has shown that, to preserve their leadership, teacher leaders must be approachable and readily accept feedback. When colleagues need assistance with technology, they will turn to teacher leaders for guidance. The teacher-leader participants in this study were patient with colleagues who were learning to use a technological tool to improve their pedagogy, which encouraged their colleagues to approach them for technological assistance. They also have caring natures and a genuine commitment to offering their students a quality education. When teacher leaders work with their colleagues on a task, collaborative forms of engagement emerge. These leaders can make it both comfortable and rewarding for their colleagues to seek assistance instead of trying 
to hide their weaknesses. During my field observation, two participants' actions reflected their accessibility and flexibility. One assisted his colleagues and offered suggestions to improve their skill with applications. The second participant helped teachers to explore the right tools to share images and other technological information. They were both patient with their colleagues who were learning how to use an application or a technological tool such as the interaction whiteboard. Their associates also desire feedback from teacher leaders on their use of technology. In addition, teacher leaders must consistently assess themselves as well as accept their colleagues' feedback to improve the leadership skills necessary to guide them through technological change. Using some form of measurement through selected indicators to consistently monitor them will have positive outcomes. This means that teacher leaders must steadily assess themselves as well as accept their colleagues' feedback. Because change in technology is constant, it presents challenges, and challenges and feedback are essential components of learning [14].

Change and technology are synonymous [4]. Therefore, for teacher leaders to sustain meaningful change, their colleagues require immediate, continuing reinforcement [6] from them to demonstrate that the teacher leaders' goals "are meaningful [and] are attainable, and [teacher leaders] provide immediate feedback to reinforce effective practice and modify ineffective practice" (p. 24) [6]. Therefore, teacher leaders' assistance to their colleagues to integrate technology into their schools requires the application of Collins' [21] flywheel analogy to the success indicators for teacher leaders. According to Collins, no single action can build a good learning environment. $\mathrm{He}$ maintained that if leaders are to stay focused on creating successful change, they must steadily push the concept of "turning the flywheel" (p. 23) [21], which Collins compared to a "massive metal disk mounted horizontally on an axle, about 30 feet in diameter, 2 feet thick, and weighing about 5,000 pounds" (p. 164). He explained that the job of a leader is to turn the wheel and keep it turning as fast and as long as possible: "You keep pushing, in an intelligent and consistent direction, and you get two turns, ... then four, ... then eight. ... The flywheel builds momentum. ... Then, at some point—breakthrough!" (p. 23) [21]. Collins noted that "each turn builds upon previous work, compounding your investment of effort. The flywheel flies forward with almost unstoppable momentum" (p. 23). "But getting the flywheel to turn, no matter how slowly, [is] considered a victory for future faster turns" (p. 96) [27]. Collins found that "no single defining action, no grand program" (p. 14) changes programs or restructures the learning environment. "Rather, the process resembled relentlessly pushing a heavy flywheel in one direction, turn upon turn, building momentum until a point of breakthrough, and beyond" (p. 14). A teacher leader must continue to do the right things no matter how long it takes, for once the wheel begins to turn, it will become nearly unstoppable. According to Collins, the capacity of teacher leaders in schools is measured according to the output delivered directly to students, and sometimes the results are challenging to measure because some of the measures are qualitative. In any event, whether measurement is quantitative or qualitative in nature, the selection of indicators will have a positive outcome. Feedback therefore makes the individuals who are participating in the act of learning passionate and engaging, which means that teacher leaders must consistently assess themselves as well as accept their colleagues' feedback. Because change in technology is constant, it presents challenges, and challenges and feedback are the essential components of learning. Asking for, receiving, and acting on feedback in purposeful ways to improve teaching and learning take time to develop. Teacher leaders' growth requires that they be more purposeful and deliberate in seeking and using feedback to expand and deepen their own learning in the field of technology.

\section{Implications for Teacher Leadership}

My study pointed to particular implications for teachers and educational leaders to further enhance learning and the support system associated with teacher leadership.

First, in the field of technology, teacher leadership plays a significant role in the integration of ICT into Saskatchewan's core curriculum, which is mandated by the Ministry of Education. To sustain technological integration and promote student learning, school administrators must adopt the recommendations of NETS for Administrators [28] to encourage teacher leaders to maintain the national educational technology standards in their schools.

Second, to maintain and sustain their leadership in technology integration, teacher leaders need feedback on their leadership activities with regard to implementing technology in the school. Both school and teacher leaders need to design a system for teacher leaders to receive frequent feedback to sustain and deepen the teaching and learning of their colleagues and to inform and deepen their own professional learning.

Third, because formal professional training is not the answer to increase teachers' use of technology in schools, teacher leaders must be able to work side by side with their colleagues. This type of informal professional development will greatly improve 
teachers' ability to relate the use of technology to their daily teaching activities.

\section{Recommendations for Further Research}

My recommendations are based on the findings, analysis, and conclusions of my study. The recommendations that follow are intended for school leaders and administrators within school districts and teacher leaders who are integrating technology into their schools; they also include recommendations for further research.

I recommend that school leaders and administrators within school districts stimulate dialogue with teachers and among themselves to develop a standard for knowledge, skills, and competencies that teachers need to be able to assume leadership roles during technological changes in their schools and districts. In addition, I recommend that school leaders and administrators facilitate the development, articulation, and implementation of a vision for the integration of technology into classroom teaching with the assistance of teacher leaders who avidly use technology in their pedagogy. They should also validate teaching and learning as the central activities of the school by encouraging side-by-side professional technological collaboration between teacher leaders and their colleagues to apply technology to their classroom teaching. School leaders and administrators should allow teacher leaders time within the school day to assist their colleagues in their classrooms and thereby offer just-in-time professional development.

I recommend that teacher leaders who are integrating technology into their schools encourage dialogue between themselves and teachers to obtain feedback. Because teacher leaders set goals for the use of technology, they need feedback to be able to define and refine the practical skills that they need to lead their colleagues during technological change. Teacher leaders as well as their colleagues need positive reinforcement on the progress of change to be able to create positive behaviours. Teacher leaders must maintain humility, a virtue that encourages learning. Leaders who are humble seek opportunities to learn something new in technology or to reinforce current knowledge. Technology brings change, and change brings the opportunity to learn to integrate technology into academic teaching. In addition, teacher leaders need to be passionate. They need to focus on technology and its use as a source of quality education for students. Last, teacher leaders need to be disciplined. They need to focus on the importance of using appropriate tools to educate students. They need to gain insights that will help them to think through the complexities of technology integration to form organized concepts that will guide all learners in the effective use of ICT.

For further research, based on the limitations of my study and to address my biases, I recommend that a survey be conducted of a large sample of teachers who use technology in schools to assess the extent to which the findings match or are similar to those in my study. I further recommend that the research be compared and analysed to create a model for teacher leadership in the area of technology integration. This research must include different perspectives as well as the implications of the success or failure of teacher leaders' side-by-side work with colleagues to teach them to use technology effectively to enhance their pedagogy.

\section{Conclusion}

In my study I explored how teacher leaders in a $\mathrm{K}$ to 12 school system maintained and retained their leadership roles while guiding their colleagues during technological change. Although a number of factors such as new developments in how people learn, the rise of the knowledge society, global connectedness, and the pervasiveness of digital technologies contribute to these changes, it is the use of technology, specifically ICT, that presents teachers with significant challenges.

The findings from my study indicate that teacher leaders must learn, explore, and share with colleagues; maintain humility and excitement while they gain knowledge and experience; encourage, trust, and create a network for colleagues; accept feedback from learners; and be approachable. The teacher leaders who participated in this study deeply believed in offering all students a quality education, and they worked diligently with their colleagues and school leaders to ensure that technology was integrated into all parts of the curriculum. This research adds to the knowledge base on the qualities that teacher leaders require to successfully lead their colleagues through technological change.

\section{References}

[1] M. Kalogiannakis, "Training With ICT For ICT from the Trainee's Perspective: A Local ICT Teaching Training Experience," Education and Information Technologies 15 (1), Springer LINK, New York, 2010, pp. 3-17.

[2] A. Schleicher, Ed., Preparing Teachers and Developing School Leaders for the 21st Century: Lessons from Around the World, OECD, 2012:

http://www.oecd.org/site/eduistp2012/49850576.pdf

(September 1, 2012). 
[3] R. Crowther, M. Ferguson, and L. Hann, Developing Teacher Leaders: How Teacher Leadership Enhances School Success, Corwin Press, Thousand Oaks, CA, 2009.

[4] M. Fullan, Change Leader: Learning to Do What Matters Most, Jossey-Bass, San Francisco, CA, 2011.

[5] E. Glazer, M. J. Hannafin, and L. Song, "Promoting Technology Integration Through Collaborative Apprenticeship," Educational Technology Research and Development 53 (4), Springer, New York, 2005, pp. 57-67.

[6] D. B. Reeves, Reframing Teacher Leadership to Improve Your School, Association for Supervision and Curriculum Development, Alexandria, VA, 2008.

[7] J. Supovitz, P. Sirinides, and H. May, "How Principals and Peers Influence Teaching and Learning," Educational Administration Quarterly 46 (1), Sage, Los Angeles, CA, 2010, pp. 31-56.

[8] G. A. Donaldson, Jr., Cultivating Leadership in Schools: Connecting People, Purpose, and Practice, Teachers College Press, New York, 2006.

[9] M. Katzenmeyer and G. Moller, Awakening the Sleeping Giant: Helping Teachers Develop as Leaders ( $3^{\text {rd }}$ ed.), Corwin, Thousand Oaks, CA, 2009.

[10] D. Gurr, L. Drysdale, and B. Mulford, "Successful Principal Leadership: Australian Case Studies," Journal of Educational Administration 43 (6), Emerald, Bingley, UK, 2005, pp. 539-551.

[11] A. Hargreaves, "Series Editor's Foreword," in S. Acker (Ed.), The Realities of Teachers' Work: Never a Dull Moment, Cassell, London, 1999, pp. vii-x.

[12] R. Anderson, "Implications of the Information and Knowledge Society for Educators," in J. Voogt and G. Knezek (Eds.), International Handbook of Information Technology in Primary and Secondary Education, Springer, New York, 2008, pp. 5-22.

[13] J. Voogt, and G. Knezek, "IT in Primary and Secondary Education: Emerging Issues," in J. Voogt \& G. Knezek (Eds.), International Handbook of Information Technology in Primary and Secondary Education, Springer, New York, 2008, pp. xxix-xlii.

[14] M. J. Koehler, and P. Mishra, "What Is Technological Pedagogical Content Knowledge?" Contemporary Issues in Technology and Teacher Education [Online serial], 2009, pp. 60-70.

[15] T. J. Sergiovanni, The Lifeworld of Leadership: Creating Culture, Community, and Personal Meaning in Our Schools, Jossey-Bass, San Francisco, 2000.

[16] B. Mulford, "When Will We Ever Learn? Another Impending Failure of Centrally Imposed Change," Perspectives on Educational Leadership, Peter Lang
International Academic Publishers, New York, 2010, pp. 12 .

[17] J. P. Spillane, R. Halverson, and J. B. Diamond, "Towards a Theory of Leadership Practice: A Distributed Perspective," Journal of Curriculum Studies 36 (1), Routledge, New York, 2004, pp. 3-34.

[18] N. Bennett, "Distributed Leadership and IT," in J. Voogt and G. Knezek (Eds.), International Handbook of Information Technology in Primary and Secondary Education, Springer, New York, 2008, pp. 597-613.

[19] K. Leithwood, "Transforming Leadership: The Move Toward Transformational Leadership," Educational Leadership 49 (5), New York, 1992, pp. 8-12.

[20] E. M. Merideth, Leadership Strategies for Teachers, Corwin Press, Thousand Oaks, CA, 2007.

[21] J. Collins, Good to Great: Why Some Companies Make the Leap . . . And Others Don't, HarperCollins, New York, 2001.

[22] M. J. Koehler and P. Mishra, "Introducing TPCK," in J. Colbert, K. Boyd, K. Clark, S. Guan, J. Harris, M. Kelly, et al., (Eds.), Handbook of technological pedagogical content knowledge (TPCK) for educators, Routledge, New York, 2008, pp. 3-29.

[23] C. Angeli and N. Valanides, TPCK in Pre-service Teacher Education: Preparing Primary Education Students to Teach with Technology. Paper presented at the Annual Meeting of the America Educational Research Association, New York, 2008, March.

[24] S. B. Merriam, Qualitative Research and Case Study Applications in Education: Revised and Expanded from Case Study Research in Education, Jossey-Bass, San Francisco, 1998.

[25] P. R. Hallman, and C. Hausman, "Principal and Teachers Relations: Trust at the Core of School Improvement," in L. J. Saha \& A. G. Dworkin (Eds.), International Handbook of Research on Teachers and Teaching 21, Part 1, Springer, New York, 2009, pp. 403416.

[26] Connie M. Moss and Susan M. Brookhart. Learning Targets: Helping Students Aim for Understanding in Today's Lesson, ASCD, Alexandria, VA, 2012.

[27] E. Betof, Leaders as Teachers: Unlock the Teaching Potential of Your Company's Best and Brightest, United Books Press, Baltimore, MD, 2009.

[28] NETS for Administrators, Essential Conditions for Implementing NETS for Administrators. http://cnets.iste.org/ adminstrators/a_esscond.html (March 9, 2008). 